\title{
Buddhism and Buddhist Business Practices
}

\author{
Samuel L Dunn ${ }^{1}$ \& Joshua D Jensen ${ }^{1}$ \\ ${ }^{1}$ Northwest Nazarene University, United States \\ Correspondence: Joshua D Jensen, Northwest Nazarene University, 623 S. University Boulevard, Nampa, Idaho \\ 83686, United States.
}

Received: January 1, 2019

Accepted: March 5, 2019

Online Published: March 8, 2019

doi:10.5430/ijba.v10n2p115

URL: https://doi.org/10.5430/ijba.v10n2p115

\begin{abstract}
The $21^{\text {st }}$ century global business environment is more diverse and interconnected than ever before. As organizations continue to expand their global reach, business professionals often find themselves having to navigate challenging cultural and religious terrain, which they may not be prepared for. While it is impossible for someone to learn the intricacies of all cultures and religions throughout the world, one can seek to learn about some of the more prominent cultures and religions of the world - particularly those they have a high likelihood of engaging with at some point in his or her business career. This paper examines Buddhism, a prevalent religion throughout many parts of the world, and discusses how its culture and beliefs are manifested through Buddhist business practices. Particular focus is placed on business in Thailand, the country with the highest percentage of Buddhists. The purpose of this paper is to provide business professionals with a basic understanding of the history of Buddhism, an overview of the major beliefs of Buddhists, and to present information that will assist business professionals in successfully navigating intercultural affairs when doing business with Buddhists in Thailand or around the world.
\end{abstract}

Keywords: global business, cross-cultural business, Thailand, Buddhism, Buddhist business practices

\section{Introduction}

Buddhism is one of the major religions of the world, with about 470 million followers. This represents about $7 \%$ of the global population. Buddhism is most prevalent in Thailand but also has a strong presence in many areas throughout the world, including China, Japan, Korea, Singapore, Vietnam, Cambodia, Laos, Sri Lanka, and Burma. Other countries that are heavily influenced by Buddhism include Tibet, Bhutan, Mongolia, surrounding areas in India, China, and Russia ("Demographics of Buddhism," n.d.). Buddhism has some presence in the United States as well, with the highest concentration of Buddhists residing in Hawaii ("Buddhists," 2018).

Our $21^{\text {st }}$ century global business environment is more geographically and culturally diverse than ever before. With the proliferation of technology worldwide, businesses throughout the world are now interconnected and can transact business with ease. Business professionals must be prepared to engage in this highly diverse business environment. This includes the ability to effectively interact with business professionals of different cultures and different religious affiliations.

Religion plays an integral role in many of the world's cultures. Business professionals must be educated regarding how religious and cultural customs impact business practices in many parts of the world. Because religion is deeply embedded in the norms and customs of society in many countries, it is impractical to claim ignorance when it comes to the religious customs of countries where business professionals will be conducting business. Today's business professionals must be able to effectively navigate the labyrinth of cultural and religious beliefs that permeate the countries where they will be engaging in business.

This paper is the fourth and final paper in a series of papers about four big religions and their business practices Islam, Judaism, Hinduism, and now Buddhism. The first paper explored Islam, and discussed how Islamic beliefs and financial principles influence Islamic business practices (Dunn \& Galloway, 2011). The second paper considered Judaism and how Jewish religious beliefs and rituals influence Jewish business practices (Dunn \& Jensen, 2018). The third paper examined Hinduism and discussed how Hindu beliefs influence business practices (Dunn \& Jensen, 2019). This final paper explores Buddhism and considers how Buddhist beliefs influence business practices in Thailand and abroad. 


\section{History of Buddhism}

Buddhism is a world religion that originated more than 2,500 years ago. Buddhism began in India in the $5^{\text {th }}$ century $\mathrm{BCE}$, and has grown over the centuries to become one of the major religions of the world. Approximately 470 million people around the world subscribe to the Buddhist religion; most of its followers are concentrated across East and Southeast Asia. However, in recent years, the religion has expanded its influence throughout the West ("Buddhism," 2017). In the United States, Buddhism continues to grow and is expected to reach more than 4.2 million followers by 2020 ("An Asian Religion," 2018).

Siddhartha Gautama, also known as the Buddha, was believed to be born circa 624 BCE (alternate date is 563 BCE) in Lumbini, a location near the Himalayas (Vail, 2018). Born to royalty, the Buddha was brought up in a wealthy home with many luxuries. However, as he grew older, he began to take notice of human suffering and became disillusioned with the pleasantries of life. He therefore took steps to renounce his splendid lifestyle and banished himself to the forest almost to the point of starvation. He turned to meditation, and at some point attained enlightenment, also known as Nirvana (Vail, 2018).

At this point the Buddha, which means "the enlightened or awakened one," began to share with others this compassion for suffering. He dedicated the remainder of his life to teaching his vision of The Middle Way and instructing people how to achieve enlightenment. "Rather than severe mortification of the body or a life of indulgence insense pleasures the Buddha advocated a moderate or 'balanced' wandering life-style and the cultivation of mental and emotional equanimity through meditation and morality" (Vail, 2018, para. 5).

The Buddha began sharing his beliefs widely and delivered his first sermon near Varanasi (a town in India). "This was a key moment in the Buddhist tradition, traditionally known as the moment when the Buddha 'set in motion the wheel of the law" (Violatti, 2013, para. 15). From there, the Buddha began to accumulate disciples, and he continued spreading his teachings throughout northern India for about 45 years. While on his deathbed, the Buddha encouraged his disciples to continue spreading the vision that they had dedicated their lives to living.

Upon his death, the Buddha's followers continued his teachings, and organized a religious movement, which laid the foundation for what would become Buddhism. The disciples continued to encourage teachers, and the Buddha's philosophies and teachings continued to spread primarily throughout northern India for the next 200 years or so. In 268 BCE, Ashoka the Great became the ruler of the Indian Mauryan Empire, and after an aggressive and bloody campaign to expand his kingdom, became remorseful and converted to Buddhism (Merryman, 2018). Ashoka the Great then declared Buddhism to be the official state religion of India. He sponsored the widespread development of many monastic schools and monasteries (Vail, 2018). "He used the Buddha's dharma to reform his government and sent Buddhist missionaries throughout India, Sri Lanka, Southeast Asia, China, and North Africa (Merryman, 2018, para. 17).

Over the years, Buddhism continued to spread throughout the East. "Buddhism however was not bound by the restrictions of the Hindu caste system and therefore more suitable for the world outside the peninsula" (Hesselink, n.d., para. 5). In the first century CE, Buddhism spread to Central Asia and China. This was about the time the Buddha was first represented in art as in human form. Statues and sculptures were constructed in areas with heavy Buddhism influence. In the second and third centuries CE, Buddhism expanded to Burma, Cambodia, Laos, Vietnam, and Indonesia. Over the next several centuries, Buddhism continued to spread throughout Southeast Asia, and eventually found its stronghold in Thailand in the tenth century CE. Around that same time, Islam began to spread quickly throughout Central Asia and eventually replaced Buddhism in many Central Asian countries ("Timeline," 2008).

The spread of Islam throughout the tenth and eleventh centuries CE eventually led to a decline of Buddhism in India. However, Buddhism was continuing to spread throughout Southeast Asia at a rapid pace. Buddhism flourished in Korea under the Koryo Dynasty in the twelfth century CE. It wasn't until the nineteenth and twentieth centuries CE that Buddhism spread beyond Southeast Asia and began moving across Europe and to the United States ("Timeline," 2008).

The growth of Buddhism had a profound impact on the world and could be visibly seen through art and architecture throughout the East, with notable structural and cultural presence in Indonesia, Vietnam, Laos, Sri-Lanka, and all throughout Southern Asia (Hesselink, n.d.). "Buddhism became a powerful cultural influence in Asia and has remained the majority religion for thousands of years" (Merryman, 2018, para. 17).

Today there are many forms of Buddhism practiced around the world. The three most predominant forms of Buddhism are region specific, and include Theravada Buddhism, Mahayana Buddhism, and Tibetan Buddhism. 
Theravada Buddhism is primarily practiced in areas of Thailand, Sri Lanka, Cambodia, Laos, and Burma. Mahayana Buddhism is prevalent in China, Japan, Taiwan, Korea, Singapore, and Vietnam. Tibetan Buddhism is most common in Tibet, Nepal, Mongolia, Bhutan, parts of Russia, and northern India ("Buddhism," 2017). The country that is most heavily influenced by Buddhism is Thailand.

\subsection{Thailand}

Today, the country with largest Buddhist population is Thailand. "The official religion in Thailand is Theravada Buddhism, practiced by more than $95 \%$ of the population and by many who reside in Laos, Myanmar, and Cambodia" (Iverson, 2017a, para. 3). The influence of Buddhism throughout Thailand is pervasive. Many majestic temples can be found throughout the country, along with many spirit houses and other signs and symbols of the religion. Many ornamental shrines and statues of Buddha grace the country. "The Buddha is considered sacred in Thailand, so any disregard for even an image of Buddha is considered disrespectful. Visitors should not touch, point, or sit higher than any of the Buddha images found in temples throughout Thailand" (Iverson, 2017b, para. 5).

Some 300,000 Buddhist monks reside in Thailand. Monks, also known as bhiksu (Sanskrit) or bhikkhu (Pali), are usually recognized by their bright orange robes, although some Monks wear robes of different color. Monks usually reside in Buddhist Monasteries and have dedicated themselves to a life of meditation and study. As with other religions, traditions have changed over the years. "In modern times, it is not unheard of for ordained bhikkhus and bhikkhunis to live outside of a monastery and hold a job. In Japan, and in some Tibetan orders, they might even be living with a spouse and children" (O’Brien, 2018, para. 20).

Next, the authors will discuss some of the major tenants and beliefs of Buddhism in an effort to prepare business professionals to effectively engage with Buddhists in the $21^{\text {st }}$ century global business environment.

\section{Buddhist Beliefs}

Siddhartha Gautama was born in 624 BCE (alternate date is 563 BCE) in Lumbini, which is now part of Nepal. When he was 29 years old he began to realize there was pain, suffering, and poverty around him. This caused him to spend many years fasting, meditating, and praying as he tried to understand the truths of life. He finally realized many truths after gaining enlightenment, or nirvana. He left home, became a wandering holy man, and began to teach those truths to people around him. As a result, he was given the title of Buddha, or Enlightened One ("Buddhism: Basic Beliefs," 2018; White, 1993). The principles he taught are called the Dhamma, or Truth.

\subsection{The Buddha's Teachings}

The Buddha taught these truths for the rest of his life. He gained many converts to his way of thinking. After decades of growth the followers of his teachings wrote down the truths in summary form. The core truths were found in the lists known as the Three Universal Truths, the Four Noble Truths, and the Eightfold Path. The Buddha urged the people not to worship him as a god.

\subsubsection{Three Universal Truths}

One of the principal teachings of the Buddha is called the Three Universal Truths. The Three Universal Truths are:

1. Everything in life is impermanent and always changing.

2. Because nothing is permanent, a life based on possessing things or persons doesn't make you happy.

3. There is no eternal, unchanging soul and "self" is just a collection of changing characteristics or attributes.

Buddhists acknowledge these truths as integral beliefs of their faith.

\subsubsection{Four Noble Truths}

Another principal teaching of the Buddha is called the Four Noble Truths. The Four Noble Truths are:

1. Human life is suffering.

2. Suffering is caused by greed.

3. Suffering can be overcome and happiness achieved.

4. The way to end suffering is to follow the Middle Path.

The way of the Middle Path is the way to nirvana. People following the Middle Path do not lead lives of indulgence or luxury, but also do not do too much fasting or living lives of hardship. The Eightfold Path gives guidance for people following the Middle Path. 


\subsubsection{The Eightfold Path}

Another principal teaching of the Buddha is the Eightfold Path. The Eightfold Path incorporates the following concepts:

1. Right understanding and viewpoint.

2. Right values and attitude.

3. Right speech.

4. Right action.

5. Right work.

6. Right effort.

7. Right mindfulness.

8. Right concentration and meditation.

\subsubsection{The Five Precepts}

Although Buddhism has subdivided into many sects, all Buddhists follow the five precepts which give guidance for daily living:

1. Do not harm or kill living things.

2. Do not take things unless they are freely given.

3. Do not carry on sexual misconduct.

4. Do not speak unkindly or tell lies.

5. Do not abuse drugs or drink alcohol.

\subsubsection{The Buddha's Teachings Continue}

After the Buddha's death at the age of 80 , his teachings were collected and written down. A collection of the Buddha's sayings is called the reipitaka, or Three Baskets. The name of Three Baskets for the Buddha's sayings came from the early practice of writing on palm leaves which were then gathered in baskets ("Buddhism: Basic Beliefs," 2018).

\subsection{Meditation}

Most Buddhists practice some form of meditation. The goal is to look within oneself to seek the truth and to understand the truths of the Buddha. The goal of the meditation is to achieve nirvana, or enlightenment. The state of enlightenment cannot be put in words - it surpasses words.

Meditation means focusing the mind to achieve an inner stillness that leads to a state of enlightenment. Meditation takes many forms:

It can be sitting quietly beside a beautiful arrangement of rocks, contemplating beauty.

It can be practicing a martial art such as karate or aikido since they require mental and physical control and strong concentration.

It can mean focusing on a riddle such as "What is the sound of one hand clapping?"

It can be contemplating a haiku or short poem that captures a moment in time.

It can be in a meditation room of a monastery.

It can involve chanting.

It can involve the use of a mandala to focus attention to the invisible point at the center of interlocking triangles.

It can involve quietly noticing one's breath as it goes in and out. It can happen anywhere at any time. ("Buddhism: Basic Beliefs," 2018, para. 9) 


\subsection{Idols}

Most Buddhist religious centers will have a statue of the Buddha. A typical pose for the Buddha is sitting with hands resting in his lap. Many times the statue will be covered in gold. Buddhists do not worship the Buddha, but venerate his memory. Buddhists are not to ask favors of the Buddha in prayer. Gifts are often left at the site which are then used by Buddhist monks.

\subsection{The Law of Dependent Origination}

The Buddha is attributed with finding the law of dependent origination, or paticca-samuppada. "One condition arises out of another, which in turn arises out of prior conditions. Every mode of being presupposes another immediately preceding mode from which the subsequent mode derives, in a chain of causes" (Buddhism, 2018, para. 25).

\subsection{What Is the Self?}

The Buddha taught that what we think of as our "self" - our ego, self-consciousness and personality - is a creation of the skandhas. Very simply, our bodies, physical and emotional sensations, conceptualizations, ideas and beliefs, and consciousness work together to create the illusion of a permanent, distinctive "me."

The Buddha said, "Oh, Bhikshu, every moment you are born, decay, and die" (O’Brien, 2017, para. 5). According to O’Brien (2017), what the Buddha meant in this statement is:

He meant that in every moment, the illusion of "me" renews itself. Not only is nothing carried over from one life to the next; nothing is carried over from one moment to the next. This is not to say that "we" do not exist - that there is no permanent, unchanging "me," but rather that we are redefined in every moment by shifting, impermanent conditions. Suffering and dissatisfaction occur when we cling to desire for an unchanging and permanent self that is impossible and illusory. Release from that suffering requires no longer clinging to the illusion. (paras. $5 \& 6$ )

The Buddha taught that all things are dynamic, and in a state of constant change. Things are "always changing, always becoming, always dying, and that refusal to accept that truth, especially the illusion of ego, leads to suffering" (O’Brien, 2017, para. 7).

\subsection{Ten Realms of Being}

Buddhists believe there are 10 realms of being. These are the levels of existence in the universe. The ten levels are divided into two sections, the first section incorporating six of the ten levels, and the second section incorporating four levels. The first six levels are:

\section{Hell or Jigokudo}

2. Hungry Ghosts or Pretas

3. Animality or Chikushodo

4. Anger or Shurado

5. Humanity or Jindo

6. Heaven

The top four levels are:
1. Learning or Shomon
2. Realization or Engaku
3. Bodhisattva or Bosatsu
4. Buddhahood

The levels are ordered, with the top level of the second section being Buddhahood. Human existence is one of the first six levels. If persons do not rigorously seek Buddhahood they will remain in one of the first six levels (Gannon, 2017; Lee, 2016).

\subsection{Concepts of God}

There is no concept of a personal God in most branches of Buddhism. Buddhism believes in the existence of neither God nor soul in the theistic sense. It is essentially a religion of the mind, which advocates present moment awareness, inner purity, ethical conduct, freedom from the problem of change, impermanence and suffering, reliance upon one's own experience, and discernment on the Eightfold Path as the teacher and guide, rather than an external authority 
other than the Dharma. "Buddhism is not centered on the concept of God as the upholder and sum of all or a universal supreme being, who is responsible for the creation and dissolution of the world and the existence of sentient beings" (Jayaram V, n.d., pp. 1-2).

\subsection{Reincarnation}

"Reincarnation" normally is understood to be the transmigration of a soul to another body after death. There is no such teaching in Buddhism. One of the most fundamental doctrines of Buddhism is anatta, or anaatman - no soul or no self. There is no permanent essence of an individual self that survives death, and thus Buddhism does not believe in reincarnation in the traditional sense, such as the way it is understood in Hinduism (O'Brien, 2017).

A gross misunderstanding about Buddhism exists today, especially about the notion of reincarnation. The common misunderstanding is that a person has led countless previous lives, usually as an animal, but somehow in this life he is born as a human being and in the next life he will be reborn as an animal, depending on the kind of life he has lived. (Tsuji, 2018, para. 2)

This is an important topic to Buddhists that is often misunderstood by outsiders. "This notion of the transmigration of the soul definitely does not exist in Buddhism" (Tsuji, 2018, para. 6)

When Buddhism was established 2,500 years ago, it incorporated a revised Hindu belief in reincarnation. Although Buddhism has two major subdivisions and countless variations in regional practices, most Buddhists believe in samsara or the cycle of rebirth. Samsara is governed by the law of karma: Good conduct produces good karma and bad conduct produces evil karma. Buddhists believe that the soul's karma transmigrates between bodies and becomes a 'germ of consciousness' in the womb. Periods of afterlife, sometimes called 'the between,' punctuate samsara, coming after death and before rebirth. (Dowdey, 2018, para. 1)

Like Hindus, Buddhists see unenlightened samsara as a state of suffering. We suffer because we desire the transient. Only when we achieve a state of total passiveness and free ourselves from all desire can we escape samsara and achieve nirvana, or salvation. Many Buddhists believe an individual can end the cycle of reincarnation by following the Eightfold Path, or the Middle Way. An enlightened being embodies the directives of the Eightfold Path: correct view, correct intention, correct speech, correct action, correct livelihood, correct effort, correct mindfulness and correct concentration.

For readers who are in cultures which have concepts of soul coming from Christianity or Islam, the question arises: If to the Buddhist there is no soul, what is it that transmigrates from physical life form to succeeding form? The answer is that it is life itself that transmigrates. Life is above the world; it is supramundane. Living physical beings such as humans or animals or plants participate in that life. As the material person or animal or plant dies the life in which that person or animal or plant shared continues on and may become associated with another person, animal, or plant.

\subsection{Buddhist Numerology}

The reader will have noticed that many things are numbered in Buddhism. There are the Four Noble Truths, the Eightfold Path, The Five Precepts, et cetera. Numbers are important to Buddhists, not just because of their explicit meanings and use as counting of objects. Numbers also have unconscious or hidden meanings, or refer to historical events, or refer to an important life principle; these numbers help us understand our lives.

Number is part of the universal language of symbolism. The spectrum of connotations of numbers is similar across different cultures, but as always, what is actually said in this shared language may be quite different. For example, the symbolism of 'One' is shared between Buddhism and Vedism, but while the Vedas yearn to return to the One, Buddhists seek to let go of the One so as to realize the only truly Buddhist number zero. (Sujato, 2010, para. 20)

Buddhist revere numbers as the meaningful symbols they can be. For example, exploring the first four counting numbers, the number one represents cosmic unity. The number two represents the division. "The original primordial Being splits into 2 beings, which simultaneously desire and oppose one another. Day/night, male/female, left/right; the world of binaries and oppositions come into being" (Sujato, 2010, para. 11). The number three integration of the Divine and the profane, while the number four is the number of completion, encompassing, perfection and balance (Sujato, 2010).

\subsection{Branches of Buddhism}


There are many branches of Buddhism. Since Buddhism does not require adherence to a particular creed, as it spread around the globe regional differences emerged as Buddhism meshed with local cultures. Over 20 main branches of Buddhism have been identified. Two main branches are the Theravada School and the Mayahana School.

\subsubsection{Theravada School}

One of the major branches with many sub-branches is the Theravada School. This school traces its origins to a council of Buddhist followers that took place about 100 years after the Buddha's death. "Employing Pali as their sacred languages, the Theravadins preserved their version of the Buddha's teaching in the Tipitaka ("Three Baskets") ("The Major Systems," 2018, para. 1).

The Theravadins accept that there is an infinite number of cosmos. Those cosmoses that are inhabited by people have three planes of existence: desire, material form, and immateriality. Each of the planes is further divided into various levels. For example, the plane of desire is divided into hell, the earth, and the heavens. Human existence is privileged.

In this cosmos, as in all others, time moves in cycles of great duration involving a period of involution..., a period of reformation of the cosmic structure, a series of cycles of decline and renewal, and finally, another period of involution from which the process is initiated once again. ("The Major Systems," 2018, para. 6)

One of the forms of meditation in the Theravada tradition involves four stages:

Closely related to a Hindu tradition of yoga, the first of these involves a process of moral and intellectual purification. Initially, the Theravadin meditator seeks to achieve detachment from sensual desires and impure states of mind through reflection and to enter a state of satisfaction and joy. In the second stage of this form of meditation, intellectual activity gives way to a complete inner serenity; the mind is in a state of 'one-pointedness' (concentration), joy, and pleasantness. In the third stage, every emotion, including joy, has disappeared, and the meditator is left indifferent to everything. In the fourth stage, satisfaction, any inclination to a good or bad state of mind, pain, and serenity are left behind, and the meditator enters a state of supreme purity, indifference, and pure consciousness. ("The Major Systems," 2018, para. 11)

\subsubsection{Mahayana School}

A second major branch of Buddhism is the Mahayana School. It also has many sub-branches, including the Avatamsaka School, the Madhyamika School, the Yogachara School, the Pure Land devotional schools, and many Meditation Schools.

For the Mahayanas, the self does not exist. The elite person is one who wants to be a Buddha and holds on entry into nirvana in order to help others. "In Bahayan, love for creatures is exalted to the highest" ("The Major Systems," 2018, para. 31). For the Mahayanas, Buddha is viewed as a supramundane being. He multiplies himself and is often reflected in other buddhas.

As the tradition developed, there emerged new texts that were considered by Mahanyana adherents to be Buddhavachana ("the word or words of the Buddha"). This new literature went far beyond the ancient canons and was believed to be the highest revelation, superseding earlier texts. In this literature the teaching is thought to operate on various levels, each adapted to the intellectual capacity and karmic propensities of those who hear it. ("The Major Systems," 2018, para. 33)

In the Mahayana tradition there are two distinct categories of individuals: the enlightened and the unenlightened. The enlightened are able to understand more of the Buddha's teachings and reflect those teachings in their daily lives.

The three bodies (trikaya; i.e., modes of being) of the Buddha are rooted in Hinayana teachings concerning the physical body, the mental body, and the body of the law. The theory of the three bodies was a subject of major discussion for the Mahayana, becoming part of the salvation process and assuming central significance in doctrine. The emanation body (nirmanakaya) is the form of the Buddha that appears in the world to teach people the path to liberation. The enjoyment (or bliss) body (sambhogakaya) is the celestial body of the Buddha to which contemplation can ascend. In the heavenly regions, or Pure Lands, the enjoyment body teaches the bodhisattva doctrines that are unintelligible to those who are unenlightened. The unmanifested body of the law (dharmakaya) already appears in the Saddharmapundarika, or Lotus Sutra, a transitional text of great importance to Mahayana devotional schools. In many Mahayana texts buddhas are infinite and share an identical nature - the dharmakaya. ("The Major Systems," 2018, para. 36) 


\subsection{Pali Language}

Pali is a Middle Indo-Aryan language originating in what is now India. The scriptures of Theravada Buddhism were originally written in Pali. "The Pali language is considered to be a composite language having several dialects and most likely is based on the language that Buddha taught in which is generally considered to be a Magadi dialect" (Prabhat, 2018, para. 4). Pali was spoken at least in the $1^{\text {st }}$ century BCE. Pali is closely related to Sanskrit. However, "Pali is not considered to be a descendant of the Sanskrit language" (Prabhat, 2018, para 3).

Next, the authors will discuss how Buddhism and the cultural and social norms of the religion are revealed throughout business in an effort to prepare business professionals to effectively engage with Buddhists in the $21^{\text {st }}$ century global business environment.

\section{Buddhist Business Practices}

Three principal doctrines of Buddhism provide the foundation for Buddhist business practices. The first is that human life involves suffering, the second is that the goal of life is to cease from suffering, and the third is that sufficiency is desirable. While Buddhists engage in economic development activity, they pursue it within the context of their core doctrines.

Thus the aim of Buddhist economic activities is the reduction of suffering instead of utility-and profit-maximization, and its possibility is confirmed by Prospect Theory. According to Prospect Theory, people are loss-sensitive. They are more sensitive to losses than gains, thus the minimization of losses could be a rational economic goal. The...Buddhist economic paradigm is not merely different from the neoclassical economic paradigm, but exactly the opposite of that. It is based on bounded rationality, non-self, imperfect decision making, and aims at the reduction of suffering. (Kovacs, 2014, p. 758)

This approach is in contrast to many other perspectives on business from around the world, whether influenced by religion or not.

Buddhist economic practice is distinguished by five characteristics.

1. Minimize suffering - an economic enterprise is worthy if it aims to reduce the suffering for every stakeholder;

2. Simplifying desires - rather than cultivating or multiplying desires, an economic enterprise should simplify desires, ensure contentment and encourage moderate consumption;

3. Practicing non-violence - the reduction of violence to the lowest possible level is identical to the reduction of market forces to a small, adaptable scale for the benefit of every participant;

4. Genuine care - the opposite of the instrumental use, treating stakeholders as goals not as tools in themselves; and

5. Generosity - people are "home-reciprocants" as they tend to behave gratefully and reciprocate favors. (Kovacs, 2014, p. 759).

Another way of talking about Buddhist economic activity is that its goal is to satisfy basic human needs while forsaking other consumer longings.

When business leaders apply these principles they must keep in mind that these goals and characteristics should also apply to all the stakeholders, especially the employees of the business. Employees are to be so situated that they can lead a balanced life, a life that allows for gainful work, but also spiritual development, and good family life. Employers must manage in such a way that the work is non-violent to the employees, other stakeholders, and to the general environment.

With these foundational principles in mind, we can move to other principles that should guide leaders as they direct businesses. Nine such principles are now articulated.

\subsection{Employee Engagement}

Leaders attempt to establish a culture of employee engagement. Research suggests that employee engagement is at the heart of a successful business.

Engagement is found where work is absorbing, and to which employees feel naturally dedicated; work that one gets wrapped up in and is energized by. Engaged employees are prepared to go beyond the call of duty and actually drive the business; they show up because they want to, not because they have to. (Beer \& Gamble, 2017, para. 6) 
As Buddhism has spread throughout the years, its philosophies and practices are subtly infused into the business environment in many areas of the world. In fact, many Buddhist philosophies have been translated into 10 Buddhist Maxims for business. For example, the second Buddhist maxim for business states "None can live without toil, and a craft that provides your needs is a blessing indeed. But if you toil without rest, fatigue and weariness will overtake you, and you will [be] denied the joy that comes from labour's end" ("10 Buddhist Maxims," n.d., para. 5).

\subsection{Spiritual Goals}

Buddhism does not negate commercial profit goals, but rather those goals must be considered in the context of spiritual goals as well. Finances must be considered in the context of meaning - where does money come from, how is it spent, how does the economic activity promote non-violence, social responsibility, and stakeholder enlightenment? What is the activity doing to enhance the quality of the larger society? All these must be taken into consideration to balance out the purely monetary goals that a firm must have.

\subsection{Be Mindful}

Buddhists believe that one should keep your head and heart calm, balanced, and objective. Do not let pride overtake you. One should not worry about positive or negative feedback. The third Buddhist maxim for business states "Develop the mind of equilibrium. You will always be getting praise and blame, but do not let either affect the poise of the mind: follow the calmness, the absence of pride" ("10 Buddhist Maxims, n.d., para. 7).

\subsection{Cause and Effect}

Buddhists believe that every happening is caused by some previous activity. As the business leader sets goals he or she must determine what will be the causes that lead to the realization of that goal. "The process is like reverse engineering. We start to trace back the logical sequence of actions that would lead to a defined goal. This process helps to define the needed steps to achieve the goal and forms a good basis for a road map for the project" (Milyutin, n.d., p. 1).

\subsection{One Step at a Time}

As the firm moves toward meeting its economic and spiritual goals, it does not need to rush to the end. Take it one step at a time using appropriate Buddhist principles. For example, the tenth Buddhist maxim for business states "A jug fills drop by drop. This classic saying from the Buddha means that things happen step by step, and that methodological piecemeal work is often superior to big splashes" ("10 Buddhist Maxims, n.d., para. 13).

\subsection{Solve a Customer's Problem}

Businesses will be successful if they discover customers' problems and help those customers resolve those problem. "So, understanding a problem our potential customers might be facing and having an empathetic attitude toward it are crucial" (Milyutin, n.d., para. 7). A customer's problem causes the customer to suffer, and businesses that help customers solve problems are views as compassionate. "Compassion is the wish for others to be rid of their sufferings" (Milyutin, n.d., para. 7).

\subsection{Embrace Change}

Reality involves change. Everything around us, including ourselves, is changing. The government, the environment, the people, our jobs, our families. We should not become fixated on a particular concept or physical object and expect it to remain changeless over time. We must embrace change, and be prepared to act in the context of the changed environment (Milyutin, n.d.).

While embracing change, we should not get wrapped up in mourning for the past or yearning for the future. Buddhist maxim number eight declares "Do not dwell in the past, do not dream of the future, concentrate the mind on the present moment" ("10 Buddhist Maxims, n.d., para. 10). This perspective demonstrates a commitment to acceptance of change without at the same time negating the realism of current existence. The ninth Buddhist maxim for business states, "You can only lose what you cling to" ("10 Buddhist Maxims, n.d., para. 11). The Buddha's teachings are clear on this - everything is in a constant state of change, and nothing is permanent. Therefore, they key to happiness is to maintain flexibility, adaptability, and a sincere desire to accept what comes as to avoid disappointment (" 10 Buddhist Maxims, n.d.).

\subsection{Do Good to All}

We must help guide our fellow humans from around the globe to move in the right direction of alleviating suffering and providing a good life for all. Not only must we think good thoughts about helpful activities, we must also, each one of us, act on those good thoughts. According to Buddhist maxim for business number seven, "Every individual 
has a responsibility to help guide our global family in the right direction. Good wishes are not sufficient; we must become actively engaged" ("10 Buddhist Maxims, n.d., para. 9). To carry this out we must be mindful of the world around us. As Buddhist maxim for business number six states, "Your work is to discover your world and then with all your heart give yourself to it" ("10 Buddhist Maxims, n.d., para. 7).

\subsection{Sufficiency Is Acceptable and Reasonable}

Much has been written about the Buddhist's view on business and economics. Schumacher (1973), as cited by Ashtankar (2015), gave pointers about Buddhist economics. 'He said that Buddhist economics is a 'Middle way' of development, aiming to achieve maximum well-being with minimum consumption" (Ashtankar, 2015, p. 17). Therefore, business professionals should not procure lavish belongings or live a life of material abundance.

In alignment with corporate social responsibility ideas of the West, Buddhists believe that personal interests should not be one's first or only pursuit. Buddhists believe that each individual has a responsibility to one another, society, and nature, and must consider the needs of these in conjunction with their lifestyle (Ashtankar, 2015).

Thus profit maximization should not be the goal of our business. Rather, we must have profits that will help us meet our basic necessities of life and ameliorate the sufferings of our customers. We must all strive to follow the Eightfold Path (Ashtankar, 2015).

\section{Doing Business in Thailand}

The country with the highest percentage of Buddhists is Thailand, with approximately $95 \%$ of the 68 million total population subscribing to Buddhism. Given the pervasive influence of Buddhism in the country, Thailand is chosen as representative of Buddhism business in practice.

Thailand is located in Southeast Asia, with neighboring countries being Laos, Cambodia, Myanmar, and Malaysia. In land mass it is approximately three times the size of the State of Florida in the United States (Central Intelligence Agency, 2018).

The country, established in the mid-1200s (1238), was formerly known as Siam until just before World War II. In the 1930s there was a revolution which led to a constitutional monarchy. The Japanese invaded Thailand in 1941. After World War II the country became an ally of the United States. In the last half of the $20^{\text {th }}$ century, the country underwent several coups of a military or civilian nature, which eventually led to a new constitution which was adopted in 2017. King Phumiphon, after being on the throne for 70 years, died in 2016; his son, Washiralongkon, became King later that year (Central Intelligence Agency, 2018).

About $40 \%$ of the land is agricultural. Forty-nine percent of the population is urbanized, with approximately 10 million people in or near Bangkok, the nation's capital. National resources include natural gas, rubber, tin, lead, and gypsum (Central Intelligence Agency, 2018).

Life expectancy at birth in 74.9 years. Of the population age 15 and older, $92.9 \%$ are literate (Central Intelligence Agency, 2018).

The legal system used in Thailand is based on civil law. Head of state is King Washiralongkon; the monarchy is hereditary. The head of government is the Prime Minister. The new constitution calls for a bicameral parliament, with 250 members in a Senate and 500 members in a House of Representatives. Next elections are expected in 2019. The judicial branch consists of a Supreme Court of Justice, a Constitutional Court, and a Supreme Administrative Court (Central Intelligence Agency, 2018).

Thailand is a member of the United Nations, the International Monetary Fund, and the World Trade Organization. "Thailand's economic fundamentals are sound, with low inflation, low unemployment, and reasonable public and external debt levels" (Central Intelligence Agency, 2018, p. 5). GDP for 2017 was $\$ 1.234$ trillion in Purchase Power Parity. At official exchange rates the 2017 estimate was $\$ 455.4$ billion. The 2017 real growth rate of the GDP was estimated at 3.9\%. Per capita GDP for 2017 was estimated at \$17,990 at Purchase Power Parity. The percentage of the population below the poverty line was estimated at 7.2\% in 2015 (Central Intelligence Agency, 2018).

There have been ongoing problems for some time along the Malaysia border with separatist groups in the predominantly Malay-Muslim provinces. Thailand has been a center of human trafficking for years, and there is a problem with drug usage and drug transportation in the country (Central Intelligence Agency, 2018).

Foreign direct investment in Thailand is welcomed. The government has several incentive programs to reduce taxation for foreign entities investing in Thailand. Special incentives are available for firms placing their international headquarters in Thailand (Central Intelligence Agency, 2018). 
Various types of legal organizations are available in Thailand. Included are partnerships, joint ventures, unincorporated joint ventures, private limited companies, public limited companies, and branch offices of foreign companies (Central Intelligence Agency, 2018).

The currency of Thailand is the Thai Baht. At the time of this writing the exchange rate with the U.S. dollar was $\$ 1=32.2156$ Bahts. Foreign currencies can be brought into and removed from Thailand (Central Intelligence Agency, 2018).

Electrification of the county is estimated at $99 \%$. Subscriptions to fixed-line telephones number 2.91 million and subscriptions to cellular phones is 121.53 million. Internet users are estimated at 32 million (Central Intelligence Agency, 2018).

The official language of Thailand is Thai. English is the second most spoken language (Central Intelligence Agency, 2018).

Foreigners desiring to enter Thailand must obtain a visa. The type of visa depends on the expected stay of the foreigner in Thailand. Visa holders must report to the Department of Immigration every 90 days. Foreigners working in Thailand must have work permits, with some exceptions (Central Intelligence Agency, 2018).

Thailand attempts to protect intellectual property. Copyrights may be obtained which protect information during the creator's life and 50 years after the creator's death. Patents for inventions hold for 20 years and patents for designs hold for 10 years. Trademarks may be registered (Central Intelligence Agency, 2018).

Foreign companies doing business in Thailand and domestic companies pay corporate income taxes. The tax system is progressive with the highest rates set at $20 \%$. Individuals pay personal income tax with rates up to $35 \%$. A Value Added Tax (VAT) of 7\% applies to many business transactions (Central Intelligence Agency, 2018).

Thirteen holidays are observed by government offices and most businesses. They are:

$\begin{array}{ll}\text { 1 January } & \text { New Year's Day } \\ \text { February, } \text { 3 }^{\text {rd }} \text { week } & \text { Makha Bucha Day } \\ \text { 6 April } & \text { Chakri Memorial Day } \\ \text { 13-15 April } & \text { Songkran } \\ \text { 5 May } & \text { Coronation Day } \\ \text { 13-15 May } & \text { National Labour Day } \\ \text { May, } 3^{\text {rd }} \text { week } & \text { Visakha Bucha Day } \\ \text { July, } \text { rd }^{\text {rd }} \text { week } & \text { Asarnha Bucha Day } \\ \text { 12 August } & \text { H. M. The Queen's Birthday } \\ \text { 23 October } & \text { Chulalongkorn Memorial Day } \\ 5 \text { December } & \text { The King's Birthday } \\ \text { 10 December } & \text { Constitution Day } \\ \text { 31 December } & \text { New Year's Eve Day). }\end{array}$

\subsection{Buddhism}

The state religion of Thailand is Theravada Buddhism. "One cannot deny the fact that in the Thai society, Buddhism has long borne much influence over the Thai way of life, thoughts and behavior. Further, Buddhism has been the main driving force in the Thai cultural development" (Limanonda, 1995, p. 77). There are over 30,000 Buddhist temples, over 300,000 monks and more than 100,000 novices. "The application of the Dhamma, the Buddha's principles, is vast in all kinds of organizations in the society" (p. 68).

A specific aspect of Buddhism that is practiced in Thailand is the principle of hierarchical order. "The vertical social relationship is characterized by a formalized superordinate-subordinate relationship" (Limanonda, 1995, p. 69). The King is considered to be the patron of religion. "You are subordinate to the old, women are subordinate to men, layman (sic) are subordinate to monks, and the villagers are subordinate to the headman" (p. 69).

The locus of introduction into the culture is found in the family. The family is to be an exemplar of the hierarchical order, and the children are to be indoctrinated into that value system in the family setting. 
Although the macroculture is collectivist, individual initiative and action is prized. It is viewed that this is an outcome of Theravada Buddhism with its emphasis on individual initiative and tolerance (Limanonda, 1995).

\subsection{Cultural Practices}

Harmony, patience, and personal equilibrium are prized values in Thailand. Do not be loud or boisterous. Being calm in one's demeanor is prized. Being publicly angry will result in loss of face.

Remember that Thailand is the land of mai pen rai, which means "it doesn't matter." Difficulties are to be ignored as much as possible. Even a death in the family should be taken with detachment. An attitude of fatalism is expected.

Thailand is the Land of Smiles. Smiling, but not giggling, is acceptable and desired. Smiling can be used to cover embarrassment and to apologize for mistakes.

Good face is very important in Thailand. Do not say or do anything that would cause another person or yourself to lose face. Loss of face in a business venture may well close down communication between principals with a subsequent loss of the venture.

Thailand is a collectivist society with much emphasis on hierarchy, seniority and age. Most business decisions are made at the top of the organization. A businessperson should know where any counterpart stands in his or her organization; expect those low in an organization to pass decision-making to persons higher up in the system.

When meeting another person, the traditional greeting is the wai, which is a gesture of bringing the palms together in front of the chest, with fingers pointing up, and a slight bow. Persons of high status are given a wai with the hands higher on the chest. If a handshake is offered, then go ahead and shake hands.

Business cards should be used. It is good practice to have the information given in Thai on one side of the card and English on the other. Business cards should be presented and received with both hands. A received business card should be accepted respectfully and handled carefully; do not put the business card in a back pocket.

Be very careful with shoes and their use. It is customary to remove shoes when entering a house. Do not show the soles of the shoe to another person, since the shoe is the dirtiest part of a person's clothes. Do not point the toes at another person, for the evil spirits in the shoe may attack the other person. Do not cross your legs with one leg placed on the other knee.

Don't touch another person's head or back. Be careful to give rite of passage to monks and to the elderly.

Thailand has a relationship society. Persons wanting to do business should establish a relationship with a key person in the partnering company, then develop and maintain the relationship over time. Developing the relationship may take several meetings and trips between the two person's offices and homes. The relationship between the two companies will be personalized in the people who work together. If the personnel change, the incoming replacement personnel will need to build a new relationship.

Contracts are typically shorter than would be the case between two western companies. Contracts contain the beginnings of the working relationship. It is realized that difficulties may come later, but because of the good relationships between the principal parties those difficulties will be resolved.

Be on time for business meetings; punctuality is appreciated. Be careful to allow plenty of time to get to the meeting if it is in Bangkok, since traffic there is notoriously bad. In going to a meeting, it is better not to go in cold. Rather, have a third party introduce you or have a letter of introduction from someone who knows the party you are visiting.

Address people by their title and surname. For example, if you are meeting with an engineer whose surname is $\mathrm{Hu}$, address him as Engineer Hu. As always, be very respectful of names.

Finally, never say anything negative about the King or any member of the royal family.

\subsection{Truth, Negotiations, and Values}

Truth comes from the Middle Way, that is, it comes from understanding both sides of a situation. "The truth develops from subjective, fatalistic feelings on the issue modified by faith in the ideologies of Theravada Buddhism" (Morrison \& Conaway, 2006, p. 509). Thais welcome information that will help them make decisions. However, persons and families take precedence over the abstract law. "The individual is responsible for his or her decisions" (Morrison \& Conaway, 2006, p. 509).

"Decision-making revolves around the hierarchical, centralized nature of authority and the dependence of the subordinate upon the superior" (Morrison \& Conaway, 2006, p. 509). 
As suggested above, face is extremely important. Status comes from karma, not one's personal success (Morrison \& Conaway, 2006). In negotiations do not force your counterpart to give you a "yes" or "no" answer. Thais will not want to give a no answer because it may interrupt harmony and cause the respondent to lose face. Do not confront the person with whom you are negotiating.

\section{Conclusion}

In conclusion, the $21^{\text {st }}$ century global business environment is more geographically and culturally diverse than at any time in history. This phenomenon will only continue going forward, as more and more countries join the global business community. As such, business professionals throughout the world must be prepared to effectively navigate the cultural and religious labyrinth that is an integral part of our current business reality. Understanding how religious customs and rituals impact business in countries that are strongly influenced by religious tradition is paramount for business professionals to be successful.

This paper has provided a brief history of Buddhism along with a brief history of Thailand, where $95 \%$ of the population are Buddhist. Subsequently, an overview of some of the more basic and fundamental beliefs held by Buddhists was presented, which led to discussion on how those beliefs are expressed through business practices among Buddhist throughout the world. The paper concluded with insight into how global business professionals can successfully conduct business with Buddhists in Thailand and abroad. The authors hope to have instilled an understanding of and appreciation for Buddhism and its influence within the global business environment.

\section{References}

10 Buddhist maxims for business. (n.d.). Business Insurance Quotes. Retrieved December 4, 2018, from http://www.businessinsurance.org/10-buddhist-maxims-for-business/

An Asian religion gains popularity in the New World. (2018, April). The Economist. Retrieved from https://www.economist.com/erasmus/2018/04/13/an-asian-religion-gains-popularity-in-the-new-world

Ashtankar, O.M. (2015). Relevance of Buddhism for business management. International Journal of Applied Research, 1(13), 17-20. http://www.allresearchjournal.com/archives/2015/vol1issue13/PartA/1-13-4.pdf

Beer, H., \& Gamble, E. (2017, October). What business can learn from Buddhism. The Conversation. Retrieved from https://theconversation.com/what-business-can-learn-from-buddhism-84413

Buddhism. (2017, October). History.com. Retrieved from https://www.history.com/topics/religion/buddhism\#section_3

Buddhism. (2018). Encyclopedia Britannica Online. Retrieved November 30, 2018, from https://www.britannica.com/topic/Buddhism

Buddhism: Basic beliefs. (2018). United Religious Initiative. Retrieved November 30, 2018, from https://www.uri.org/kids/world-religions/buddhist-beliefs

Buddhists. (2018). Pew Research Center. Retrieved November 27, 2018, from http://www.pewforum.org/religious-landscape-study/religious-tradition/buddhist/

Central Intelligence Agency. (2018). Thailand. In The World Factbook. Retrieved December 4, 2018, from https://www.cia.gov/library/publications/the-world-factbook/geos/th.html

Demographics of Buddhism. (n.d.). Georgetown University Berkley Center for Religion, Peace, \& World Affairs. Retrieved November 27, 2018, from https://berkleycenter.georgetown.edu/essays/demographics-of-buddhism

Dowdey, S. (2018). How reincarnation works. HowStuffWorks. Retrieved December 4, 2018, from https://people.howstuffworks.com/reincarnation2.htm

Dunn, S.L., \& Galloway, R.R. (2011, November). Islam, Islamic finance, and Christianity. Journal of Biblical Integration in Business, 14(1), 43-67.

Dunn, S.L., \& Jensen, J.D. (2018, July). Judaism and Jewish business practices. International Journal of Business Administration, 9(4), 73-88. https://doi.org/10.5430/ijba.v9n4p73

Dunn, S.L., \& Jensen, J.D. (2019, January). Hinduism and Hindu business practices. International Journal of Business Administration, 10(1), 33-48. https://doi.org/10.5430/ijba.v10n1p33

Gannon, J. (2018, December). The ten spiritual realms: According to an ancient Japanese Buddhist priest from the $\begin{array}{lllll}\text { Kamakura } & \text { period. } & \text { Evolution. } & \text { Retrieved }\end{array}$ 
https://www.collective-evolution.com/2017/12/30/the-ten-spiritual-realms-according-to-an-ancient-japanese-bu ddhist-priest-from-the-kamakura-period/

Hesselink, K. (n.d.). History of Buddha and Buddhism. Retrieved November 26, 2018, from http://www.katinkahesselink.net/tibet/his.html

Iverson, K. (2017a, October). Everything you need to know about Buddhism in Thailand. The Culture Trip. Retrieved https://theculturetrip.com/asia/thailand/articles/everything-you-need-to-know-about-buddhism-in-thailand/

Iverson, K. (2017b, March). An etiquette guide to visiting temples in Thailand. The Culture Trip. Retrieved from https://theculturetrip.com/asia/thailand/articles/an-etiquette-guide-to-visiting-temples-in-thailand/

Jayaram, V. (n.d.). The Buddha on God. Hinduwebsite.com. Retrieved November 30, 2018, from https://www.hinduwebsite.com/buddhism/buddhaongod.asp

Kovacs, G. (2014). The theoretical foundation of Buddhist management practices. Journal of Management Development, 33(8/9), 751-762. https://doi.org/10.1108/JMD-09-2013-0120

Lee, M. (2016, May). Ten worlds. Buddhism: Fundamentals of Buddhism. Retrieved from https://www.lotus-happiness.com/ten-worlds-ten-spiritual-realms-in-buddhist-cosmology/

Limanonda, B. (1995). Families in Thailand: Beliefs and realities. Journal of Comparative Family Studies, 26(1), 67-82. Retrieved from https://www.jstor.org/stable/41602367?seq=1\#page_scan_tab_contents

Merryman, L. (2018, April). The story and spread of Buddhism. International Mission Board. Retrieved from https://www.imb.org/2018/04/27/story-spread-buddhism/

Milyutin, Y. (n.d.). 5 Buddhist principles to help run a business. Study Buddhism. Retrieved December 4, 2018, from https://studybuddhism.com/en/essentials/how-to/5-buddhist-principles-to-help-run-a-business

Morrison, T., \& Conaway, W.A. (2006). Kiss, bow, or shake hands (2nd ed.). Avon, MA: Adams Media.

O'Brien, B. (2017, July). Rebirth and reincarnation in Buddhism. Thought Co. Retrieved from https://www.thoughtco.com/reincarnation-in-buddhism-449994

O’Brien, B. (2018, July). About Buddhist monks. Thought Co. Retrieved from https://www.thoughtco.com/about-buddhist-monks-449758

Prabhat, S. (2018, January). Difference between Sanskrit and Pali. DifferenceBetween.net. Retrieved from http://www.differencebetween.net/miscellaneous/culture-miscellaneous/difference-between-sanskrit-and-pali/

Schumacher, E.F. (1973). Small is beautiful: Economics as if people mattered. New York: Harper.

Sujato, B. (2010, April). Buddhist numerology. Retrieved from https://sujato.wordpress.com/2010/04/15/buddhist-numerology/

The major systems and their literature. (2018). Encyclopedia Britannica Online. Retrieved December 4, 2018, from https://www.britannica.com/topic/Buddhism/The-major-systems-and-their-literature

Timeline of Buddhist history. (2008). Buddha Dharma Education Association \& BuddhaNet. Retrieved November 27, 2018, from https://www.buddhanet.net/e-learning/history/b_chron-txt.htm

Tsuji, T. (2018). On reincarnation. Buddha Dharma Education Association \& BuddhaNet. Retrieved from https://www.buddhanet.net/e-learning/reincarnation.htm

Vail, L.F. (2018). The origins of Buddhism. Center for Global Education-Asia Society. Retrieved November 16, 2018, from https://asiasociety.org/education/origins-buddhism

Violatti, C. (2013, December). Siddhartha Gautama. Ancient History Encyclopedia. Retrieved from https://www.ancient.eu/Siddhartha_Gautama/

White, B. (1993). A five minute introduction. Buddha Dharma Education Association \& BuddhaNet. Retrieved from https://www.buddhanet.net/e-learning/5minbud.htm 